\title{
Conceptual design of a measurement network of the global change
}

\author{
P. Hari ${ }^{1}$, T. Petäjä ${ }^{2}$, J. Bäck ${ }^{1}$, V.-M. Kerminen ${ }^{2}$, H. K. Lappalainen ${ }^{2,3}$, T. Vihma ${ }^{3}$, T. Laurila ${ }^{3}$, Y. Viisanen ${ }^{3}$ T. Vesala $^{2}$, \\ and M. Kulmala ${ }^{2}$ \\ ${ }^{1}$ Department of Forest Sciences, University of Helsinki, Helsinki, Finland \\ ${ }^{2}$ Department of Physics, University of Helsinki, Helsinki, Finland \\ ${ }^{3}$ Finnish Meteorological Institute, Helsinki, Finland
}

Correspondence to: P. Hari (pertti.hari@helsinki.fi)

Received: 29 June 2015 - Published in Atmos. Chem. Phys. Discuss.: 5 August 2015

Revised: 18 December 2015 - Accepted: 29 December 2015 - Published: 28 January 2016

\begin{abstract}
The global environment is changing rapidly due to anthropogenic emissions and actions. Such activities modify aerosol and greenhouse gas concentrations in the atmosphere, leading to regional and global climate change and affecting, e.g., food and fresh-water security, sustainable use of natural resources and even demography. Here we present a conceptual design of a global, hierarchical observation network that can provide tools and increased understanding to tackle the inter-connected environmental and societal challenges that we will face in the coming decades. The philosophy behind the conceptual design relies on physical conservation laws of mass, energy and momentum, as well as on concentration gradients that act as driving forces for the atmosphere-biosphere exchange. The network is composed of standard, flux and/or advanced and flagship stations, each of which having specific and identified tasks. Each ecosystem type on the globe has its own characteristic features that have to be taken into consideration. The hierarchical network as a whole is able to tackle problems related to large spatial scales, heterogeneity of ecosystems and their complexity. The most comprehensive observations are envisioned to occur in flagship stations, with which the process-level understanding can be expanded to continental and global scales together with advanced data analysis, Earth system modelling and satellite remote sensing. The denser network of the flux and standard stations allows application and up-scaling of the results obtained from flagship stations to the global level.
\end{abstract}

\section{Background}

The global environment is changing rapidly due to anthropogenic influences. Grand challenges, such as climate change, air pollution, food and fresh-water security, biodiversity, demography, energy production, sustainable use of mineral resources, chemicalization, dispersion of epidemic diseases, acidification and eutrophication, are closely connected with each other (e.g., Bonan, 2008; Lim et al., 2012; IPCC, 2013; Ren et al., 2013; Silva et al., 2013; Wheeler and von Braun, 2013; Challinor et al., 2014). Since we have only one planet, it is crucial to carefully investigate the limits of Earth for the sustainable well-being of both nature and mankind (e.g., Rockström et al., 2009).

The atmosphere forms a major part of the environment to which life on Earth is sensitively responsive. The atmosphere closely interacts with the biosphere, hydrosphere, cryosphere and lithosphere on timescales from seconds to millennia (Wanner et al., 2008). Changes in one of these components are directly or indirectly communicated with the others via intricately-linked processes and feedbacks. In recent years, a lot of research has been motivated by the recognized importance of the atmospheric composition to the global radiation budget, hydrological cycle, forest growth, food production and human health (Savva and Berninger, 2010; IPCC, 2013; Tai et al., 2014; Rosenfeld et al., 2014). The concentrations of greenhouse gases (GHG), reactive trace gases and aerosol particles are tightly connected with each other via physical, chemical and biological processes occurring in the atmosphere, biosphere and at their interface (Arneth et al., 2010; Carslaw et al., 2010; Nobre et al., 2010; Mahowald, 2011; Kulmala et al., 2014a). Human and societal actions, such as 
emission policy, forest management and land use change, as well as various natural feedback mechanisms involving the biosphere and atmosphere, have substantial impacts on the complicated couplings between atmospheric aerosol particles, gaseous compounds, air quality and climate (Brasseur and Roeckner, 2005; Arneth et al., 2009; Raes et al., 2010; Fiore et al., 2012; Shindell et al., 2012; Ding et al., 2013; Horton et al., 2014).

Human actions have altered the composition of the atmosphere for centuries. The atmospheric composition change was slow in the beginning and caused mainly by the land use change, such as turning forests into agricultural land (e.g., Raupach and Ganadell, 2010). The increasing use of fossil fuels during the nineteenth century initiated a rapid growth of carbon dioxide $\left(\mathrm{CO}_{2}\right)$ flux to the atmosphere, as a result of which the atmospheric $\mathrm{CO}_{2}$ concentration started to increase, at first slowly and then more rapidly during the last few decades (IPCC, 2013), exceeding $400 \mathrm{ppm}$ in 2014 (http://www.esrl.noaa.gov/gmd/ccgg/trends/). In addition to $\mathrm{CO}_{2}$, emissions and atmospheric concentrations of several other gaseous compounds and aerosol particles have increased considerably during the industrial period (Lamarque et al., 2010; Granier et al., 2011). Atmospheric concentrations of methane and $\mathrm{N}_{2} \mathrm{O}$, the two other major $\mathrm{GHG}$ species, have increased by factors of about 2.5 and 1.2 since pre-industrial times (IPCC, 2013). Short-lived trace gases and aerosol particles are very unevenly distributed in the atmosphere, in addition to which their past concentration changes have been very different in different regions of the world (e.g., Naik et al., 2013; Chin et al., 2014).

The atmospheric composition change has affected our climate since pre-industrial times. The globally averaged, combined land and ocean surface temperature shows a warming of $0.85^{\circ} \mathrm{C}\left(0.65-1.06^{\circ} \mathrm{C}\right)$ over the period $1880-2012$ (IPCC, 2013). Observed temperature changes have not been homogeneous but subject to large spatial and temporal variability due to combined, yet poorly quantified effects by GHGs, atmospheric aerosols and internal changes in the climate system (Estrada et al., 2013; Jones et al., 2013; Santer et al., 2013). Future climate change is likely to be even more dramatic. IPCC (2013) concludes that if the GHG emissions will continue on a business-as-usual basis, the global mean temperature is projected to increase by $3-5^{\circ} \mathrm{C}$ by the year 2100 compared with the recent decades. The Arctic region has warmed more than twice the global-average rate during the last 3-4 decades and, depending on future emissions, it will warm between about $2.2 \pm 1.7^{\circ} \mathrm{C}$ and $8.3 \pm 1.9^{\circ} \mathrm{C}$ by the end of this century (IPCC, 2013, Overland et al., 2013). It is expected that the northern regions, i.e., the land and ocean areas lying $45^{\circ} \mathrm{N}$ latitude or higher, will undergo consequential change during the next 40 years (IPCC, 2013).

The biosphere, i.e., plant and animal kingdoms, react to both climate change and atmospheric composition change. For example, the numbers of individuals per unit area, species composition (biodiversity) and annual biomass pro- duction per unit area are influenced by changing climate variables (Elmendorf et al., 2012). The metabolism of vegetation and atmospheric chemical reactions both influence and respond to changes in the concentrations of atmospheric trace gases and aerosol particles (Baldocchi, 2008). $\mathrm{CO}_{2}$ is an important raw material for the organic molecules formed in photosynthesis, and its availability limits the growth and functioning of all autotrophic organisms (i.e., plants, algae and cyanobacteria). The present increase, about $30 \%$, of atmospheric carbon dioxide has enhanced photosynthesis (Urbanski et al., 2007; Müller et al., 2007), and consequently the metabolism of autotrophs produces more carbon skeletons now than 200 years ago for growth, reproduction and all associated biosynthetic processes.

The system responses to changes are often linked with each other and form chains of interacting processes between the Earth system compartments: atmosphere, vegetation, soil and aquatic systems. At the same time, these compartments interact strongly with human activities. Chains of interacting processes may form a feedback loop, in which an initial change in a quantity (temperature, $\mathrm{CO}_{2}$ concentration etc.) will either amplify or suppress this change (e.g., Schwartz, 2011). Earth System feedbacks are numerous and, evidently, not all relevant feedback loops have even been identified yet. Identification and process-level understanding of key feedback loops are central to finding sustainable solutions to Grand Challenges in both global and regional scale. Since feedback loops connect the atmosphere, vegetation, soil, cryosphere and aquatic systems with each other in a complicated manner, and since the whole Earth system is responding to the anthropogenic emissions into the atmosphere, studying single processes or phenomena alone is clearly insufficient for the proper understanding of the present global change.

The work towards European infrastructure has been made via the European level ESFRIs (European Strategy Forum on Research Infrastructures) approach, even though the environmental research infrastructure field is still very fragmented in Europe. Many coordinated observation systems have already been established or are in a process towards large-scale observation systems. Here, one of the most advanced in the frame of environmental systems are ICOS (Integrated Carbon Observation System), ANAEE (Infrastructure for Analysis and Experimentation on Ecosystems), and ACTRIS (Aerosols, Clouds, and Trace gases Research InfraStructure Network), as well as GOOS (Global Ocean Observing System), IASOA (International Arctic Systems for Observing the Atmosphere), LifeWatch, SIOS (Svalbard Integrated Observation System), InGOS (Integrated Non$\mathrm{CO}_{2}$ Greenhouse Gas Observing System), EXPEER (Distributed infrastructure for EXPErimentation in Ecosystem Research). Furthermore, the steps towards integration of systems have been taken via the RI cluster projects ENVRI and COOPEUS. Several international Earth observation systems and networks exist, including EMEP (European Monitor- 
ing and Evaluation Program), GAW-WMO (Global Atmosphere Watch Program by World Meteorological Organization), FluxNet (global network of micrometeorological tower sites), AERONET (AErosol RObotic NETwork), SolRadNet (Solar Radiation Network) and EARLINET (European Aerosol Research LIdar NETwork).

Although these networks provide high-quality observations, their perspective is typically limited to only a certain type of observation, such as greenhouse gases, trace gases, atmospheric aerosols or ecosystem functions. However, there are interactions between the components and feedback loops that are associated with the responses of the atmosphere, forests, soil, tundra, oceans etc. to the global change. These feedback loops play a very important role in the current global change. For example, increasing atmospheric $\mathrm{CO}_{2}$ concentration increases the air temperature that enhances the decomposition of soil organic matter, resulting in an increasing $\mathrm{CO}_{2}$ flow into the atmosphere. The number of known feedback loops is quite large (Kulmala et al., 2004; Arneth et al., 2010; Paasonen et al., 2013; Kulmala et al., 2014a; Petäjä et al., 2016), and it is very plausible that there still are unidentified important feedback loops. A proper quantification of the feedback loops necessitates having coherent measurements of the processes involved in these loops in all types of ecosystems on the globe.

A true integration and interoperability between the existing networks is still a work in progress and demands a comprehensive concept where all these domains are considered simultaneously. Furthermore, there are gaps in our theoretical knowledge and observations that hinder and slow down the necessary use of effective policy interventions. Development of the present theories, construction of new ones, and testing of theories against field measurements and time series describing the development of the Earth system are urgently needed.

One major challenge associated with global observations is the inclusion of challenging and less accessible observational areas, such as Russia and China with a clear concept of harmonized observations, which relies on existing infrastructures and gap-filling infrastructure development in target areas (Kulmala et al., 2011). High-quality observations in these regions are of crucial importance for the predictions of future state of the Earth system. This is one of the main aims of the PEEX (Pan-Eurasian Experiment) program (Lappalainen et al., 2014; Kulmala et al., 2015). The two-dimensional hierarchical station network comprising of coordinated operation of atmospheric, oceanic and ecosystem observations is now suggested in this work.

The aim of our paper is to outline the theoretical basis and the structure of global comprehensive station network to investigate the changing Earth system, including different feedbacks and interactions.

\section{Theoretical background of the station network}

The Earth surface is covered with diverse ecosystems that depend on processes occurring both below the surface (oceans and lithosphere) and above the surface (atmosphere). The most important processes in this regard are absorption and conversion of solar irradiation into chemical energy, absorption of elements and/or matter from oceans, lithosphere and atmosphere with the help of this energy, and building up new biomass from the acquired raw materials and energy.

Versatile ecosystems, from forests to tundra and from deserts to oceans, cover the surface of the globe. Solar radiation plays a crucial role in the behavior of these ecosystems by providing energy for several phenomena taking place in vegetation, soil, water and atmosphere. The energy demanding phenomena are often the first steps in long chains of processes forming feedback loops. Conversion of material and energy into other forms is characteristic for such energy demanding phenomena.

The construction of a global measurement network is based on well-identified regularities generated by the chains of processes that characterize the behavior of material and energy in atmosphere, vegetation, soil and water on the globe. We have adopted the following regularities in designing the required set of measurements:

1. Mass, energy and momentum are being conserved.

2. Metabolic, physical and chemical processes convert material and energy into other forms at molecular levels.

3. These processes generate concentration, temperature and pressure differences.

4. Concentration, temperature and pressure differences give rise to material and energy flows.

5. Material and energy flows combine molecular phenomena to the behavior of larger-scale components in the system.

6. These flows convey interactions in the atmosphere, vegetation, soil and water, and especially between ecosystems, atmosphere and lithosphere.

7. These flows also change the material and energy pools in the atmosphere, vegetation, soil and water.

8. Feedback loops convey the responses to the global level.

9. Chemical, physical and metabolic processes transform raw materials to end products. These processes are affected, e.g., by temperature, radiation, concentrations of raw materials, end products and enzymes conveying the conversion.

The processes converting material and energy to other forms are engines of material and energy flows taking place in the 
atmosphere, vegetation, soil and water. Such processes generate concentration, temperature and pressure differences in small scales that give rise to the flows of material and energy. The transition from these small to larger spatial scales takes place via material and energy flows. The processes converting energy and material to other forms along with material and energy fluxes provide a common way to communicate for investigating the atmosphere and ecosystems in the context of global change. This common language enables knowledge flow between disciplines and common studies between atmospheric, forest, and aquatic researches.

The planning and construction of the global measurement network is facing three fundamental challenges; (i) the heterogeneity of the area, (ii) the complexity of the functional units and (iii) the large area of the globe. These challenges can, however, be treated with proper planning and implementation of the stations to form a hierarchical network (see also Hari et al., 2009).

\subsection{Heterogeneity}

A characteristic feature of the Earth surface is its large variability, even though there are several types of homogenous areas like the oceans, ice sheets, tundra and forests. The heterogeneity of Earth surface is generated mainly by the great differences between the homogenous areas. The specific aspects of each homogenous surface type should be taken into consideration in the global measurement network. In this way, the heterogeneity is divided into variations between homogenous areas and variations within each homogenous area.

\subsection{Complexity}

The homogenous cover type areas are complex entities, as there are metabolic, physical and chemical processes running simultaneously and interacting with each other. Measuring all the relevant phenomena simultaneously is needed in the whole ecosystem. Special attention should be paid to the feedback loops connecting various Earth surfaces with the atmosphere. This can be achieved with comprehensive measurement stations, called flagship stations, where all the relevant fluxes and processes are being measured simultaneously.

\subsection{Large area}

A large number of measurement stations are needed to cover the huge area of the globe. However, comprehensive measurement stations are expensive to construct and maintain. The number of comprehensive stations remains, therefore, too low. The knowledge from comprehensive measurement stations can be expanded to larger spatial scales with additional measurements of the key ecosystem phenomena. Measuring fluxes is quite straightforward with current instrumentation, in addition to which fluxes play a key role in the func- tioning of ecosystems. Therefore, stations concentrating on fluxes enable utilization of knowledge obtained from comprehensive stations. The existing network of weather stations has provided valuable results for over 100 years. These stations can be connected with global flagship and flux stations with additional instrumentation that measures gas and aerosol concentrations, making them so-called standard stations.

The above considerations lead to a hierarchical network of measurement stations. Flagship stations provide a fundamental understanding of phenomena taking place at the Earth's surface, whereas flux/advanced and standard stations allow expanding these results to each land-cover type or oceanic region. More specifically, we obtain a global measurement station network consisting of ecosystem-specific components of varying complexity and a general component that makes atmospheric observations in each ecosystem. Forests, peat land and/or tundra, savannah, crop lands and lakes and/or rivers are examples of land-cover types, forming natural functional units. Urban areas are of specific importance as they influence human health and emit large amounts of reactive compounds to the atmosphere. Oceanic areas need to be included as well due to their very large contribution to the Earth surface and thereby to material and energy fluxes to the atmosphere.

The price and necessary work to construct and maintain measurement systems increase when stations become more complex, starting from a standard level and evolving to the advanced and ultimately to the flagship level. The stations consist of two components, the atmospheric and ecosystemspecific observations, and follow the general principles:

1. The focus in observations is the material and energy fluxes.

2. The observations need to be performed continuously, day and night, winter and summer.

3. The time resolution depends on the processes that are studied, varying from $20 \mathrm{~Hz}$ to years or decades.

4. The detection limits of instruments in all locations need to be low enough to catch the temporal and spatial variation of the measured gas and aerosol concentrations.

5. The data quality procedures, distribution and storage format need to be harmonized within the network.

Several combinations of ecosystem and atmosphere components are needed at each measurement station. We outline the combination of ecosystem and atmospheric components in the global station network in Table 1. Note that the terminology regarding the division to atmospheric and ecosystem stations may differ from those used in other contexts, like in ICOS an atmospheric station refers to tall towers and an ecosystem station to flux towers. 
Table 1. The structure of the current and envisioned global network of measurement stations. The values indicate the approximate number of stations having different levels of atmospheric and ecosystem-specific observations in the current and envisioned (in parenthesis) measurement network. Besides expanding the existing network, the plan is to develop it toward a better balance between ecosystem-specific and atmospheric observations, i.e., to move toward the diagonal of the matrix.

\begin{tabular}{lllll}
\hline & & \multicolumn{3}{c}{ Ecosystem component } \\
\cline { 3 - 5 } & & Standard & Flux & Flagship \\
\hline Atmospheric & Standard & $10000(10000)$ & 700 & \\
component & Flux & 100 & $100(500)$ & \\
& Flagship & & & $2(50)$ \\
\hline
\end{tabular}

\section{Conceptual planning of the measurement stations}

The measurement stations include three components, i.e., ecosystem-specific, atmospheric and aquatic measurements. The ecosystem-specific components differ from each other greatly between the different ecosystems because the important processes and fluxes may be different for each ecosystem. The atmospheric component has less ecosystem-specific features, but there are also important location-specific aspects in the atmosphere that are connected with various feedback loops.

In the planning of a measurement station we need to identify all relevant processes and fluxes in the ecosystem under consideration. The amount of processed or transported material or energy, together with the feedbacks involved, determines the relevance of the processes and fluxes. Then we need to analyze the special features of the processes and fluxes to be measured.

The common understanding, based on processes, material and energy fluxes and pools provide the backbone for the construction of the measuring station network. The planning of measuring systems of atmosphere, ecosystems and oceans is based on common stepwise approach as follows:

a. to analyze the structure of the studied system,

b. to identify the processes, energy and material fluxes,

c. to identify the material and energy pools,

d. to determine the proper measuring frequency,

e. to determine the needed measuring accuracy and precision,

f. to choose instruments.

The common language and similar structure of the measuring stations enable proper information and knowledge flow between researchers working at the measuring stations and also between disciplines in the measuring station network.

The number of different ecosystems is quite large, and consequently the number of different measurement stations is still larger. However, although there are differences in the stations, their planning follows the above six steps. We demonstrate with three examples the planning procedures of ecosystem, atmospheric and aquatic components.

\subsection{Atmosphere}

The globe has a thin layer of gases above the oceans and land, called the atmosphere. The composition of the atmosphere is dominated by nitrogen and oxygen molecules, contributing together with argon to more than $99 \%$ of the total volume of air. The most important greenhouse gases, i.e., carbon dioxide, methane, nitrous oxide and water vapor, are also abundant, in addition to which the atmosphere contains a large number of trace gases having volume mixing ratios less than one part per million. These latter compounds include carbon monoxide, ozone, sulphur dioxide, nitrogen oxides, ammonia, various other sulphur- or nitrogen-containing gases, and a very large number of different organic compounds. In addition to gaseous compounds, there are small liquid or solid particles, called aerosol particles, throughout the atmosphere. Concentrations of water vapor, most trace gases and aerosols particles vary greatly with both space and time in the atmosphere (e.g., Seinfeld and Pandis, 2006; Inness et al., 2013).

The troposphere, which extends from the Earth's surface up to about $18 \mathrm{~km}$ in the tropics and up to a few $\mathrm{km}$ near the poles, contains almost $90 \%$ of the mass of the atmosphere and is responsible for most of the atmospheric variability (Brasseur et al., 1999). Important phenomena taking place in this layer include the meteorological processes that create our daily weather patterns, atmospheric chemistry and transport which together with emissions dictate concentrations of trace gases and aerosol particles, as well as formation and evolution of cloud systems essential to the global hydrological cycle. Clouds, together with greenhouse gases and aerosols have also large influences on the Earths' energy balance, and thereby on global climate change as well as the amount of radiation reaching the Earth surface (Haywood et al., 2011; Stephens et al., 2012; IPCC, 2013).

The lowest region of the troposphere where surface effects are important is called the planetary boundary layer. The typical thickness of this layer is about $1 \mathrm{~km}$, even though it varies considerably with the time of day depending mainly on meteorological conditions (e.g., Brasseur et al., 1999). The vast 
majority of both natural and anthropogenic emissions take place within or into this layer. Concentrations of aerosol particle and trace gases in the planetary boundary layer determine their health effects and impacts on vegetation. The planetary boundary layer connects land ecosystems and oceans closely with the atmosphere via material and energy flows.

\subsubsection{Standard station}

Standard stations provide measurements of such properties that act as key drivers for the most important processes in land-atmosphere interactions. The observations are made at the ground level with a dense geographical grid to provide a good spatial coverage. The measurements include the following:

1. standard meteorological quantities in the atmosphere (temperature, relative humidity, wind direction, wind speed, precipitation, solar radiation)

2. one additional measurement, user selectable, such as:

a. solar radiation in different wavelength regimes (PAR, global, net)

b. measurements on the properties of the soil and ground: temperature profiles, soil water content and tension, snow depth and water content

c. concentrations of some trace gases (e.g., $\mathrm{SO}_{2}, \mathrm{O}_{3}$, $\left.\mathrm{NO}_{x}, \mathrm{CO}\right)$

d. number concentration of aerosol particles

\subsubsection{Flux station}

Flux stations are advanced versions of standard stations with the following capacity:

1. all measurements made at the standard stations, including the user-selectable components

2. aerosol particle number concentrations and size distributions

3. upward and downward longwave radiation, sensible heat, and latent heat/water vapor fluxes

4. flux measurements of a user-selectable set of trace gases, such as $\mathrm{CO}_{2}, \mathrm{O}_{3}, \mathrm{SO}_{2}, \mathrm{O}_{3}, \mathrm{NO}, \mathrm{NO}_{2}, \mathrm{~N}_{2} \mathrm{O}, \mathrm{CH}_{4}$, $\mathrm{CO}$ and volatile organic compounds (VOC)

Flux stations host focused campaigns, the purpose of which is to determine connections between the fluxes and environmental and ecosystem factors.

\subsubsection{Flagship stations}

Flagship stations provide state-of-the-art observations of atmospheric concentrations and material and energy fluxes in the atmosphere-biosphere continuum. An atmospheric flagship station provides a comprehensive monitoring of processes and contributing factors at high spatial and temporal resolution, such as

1. all observations conducted in standard and flux stations

2. aerosol chemical composition

3. characterization of aerosol vertical profile and boundary layer structure (lidar)

4. atmospheric ion and cluster size distribution

5. comprehensive characterization of trace gas (volatile and extremely low-volatile organic compounds, sulfuric acid, ammonia, methane) and oxidant concentrations

6. advanced characterization of atmospheric turbulence and trace gas and aerosol fluxes in multiple heights incl. below canopy

7. cloud characterization (cloud radar)

8. advanced characterization of solar radiation (spectral dependency)

9. reflected and absorbed radiation (PRI, chlorophyll fluorescence)

The flagship station is involved in development of novel instrumentation and provides benchmarking and in-depth comparison of the novel instruments with the existing data. The flagship station regularly hosts intensive and comprehensive field studies and performs inter-platform calibrations and verifications (in situ, satellite, airborne).

The flagship stations consists of a tall mast $(>100 \mathrm{~m}$ in height) and its instrumentation. The instrumentation measures temperature profiles, three-dimensional wind velocities, aerosol size distributions, concentrations and fluxes of trace gases, down and upward radiation spectra, and energy fluxes.

\subsection{Forest ecosystem}

Trees, ground vegetation and soil form a forest ecosystem. The mass of trees is such that ecosystems is of the order of $100000 \mathrm{~kg} \mathrm{ha}^{-1}$, whereas that of ground vegetation is usually less than $1000 \mathrm{~kg} \mathrm{ha}^{-1}$ (Ilvesniemi and Liu, 2001; Ilvesniemi et al., 2009). Large carbon polymers (proteins, lipids, cellulose, lignin and starch) form the structure of cells. The litter fall feeds the organic component of soil and the same polymers are the dominating carbon compounds in the soil. The carbon compound pools in trees and soil are large and of similar magnitude (Ilvesniemi et al., 2009).

Vegetation synthesizes sugars in photosynthesis using atmospheric $\mathrm{CO}_{2}$ and water as raw material and solar radiation as energy source for the synthesis. Metabolism uses sugars as the raw material for the synthesis of the macromolecules 
and as sources of energy. The lifetime of most vegetation tissues is rather short, and the senescent tissues enter the carbon pool in the soil. Microbes cleave the macromolecules in the litter with extra cellular enzymes and utilize the resulting small molecules for growth and as a source of energy for metabolism in a process called respiration. Respiration results in the release of $\mathrm{CO}_{2}$ to the atmosphere. Transpiration is a prerequisite of photosynthesis since diffusion transports $\mathrm{CO}_{2}$ and water molecules into stomatal pores in leaves. A large variety of volatile organic compounds is synthesized in the metabolism of vegetation and microbes, resulting in emission of organic compounds (Laothawornkitkul et al., 2009).

Absorption and emission of radiation, along with transpiration and condensation of water, generates temperature differences in the canopies, giving rise to turbulent and laminar flow of air. The turbulent mixing of air reduces temperature and concentration differences in air. The airflow transports $\mathrm{CO}_{2}$ into leaves and water vapor and biogenic organic compounds away from the vicinity of leaves.

\subsubsection{Standard stations}

Forest standard station measures the basic features and phenomena in forests. They include the following measurements:

1. standard stand measurements at a forest site (tree species, diameter, height and volume)

2. standard soil measurements (amount of soil organic matter, size distribution of mineral soil particles and concentration of main nutrients)

\subsubsection{Advanced stations}

When we expand the standard station measurements to the development and fluxes of the stand we obtain the advanced station. They include the following measurements:

1. the measurements conducted at standard forest stations

2. measurement of $\mathrm{CO}_{2}$, water and heat fluxes between the ecosystem and atmosphere

3. retrospective measurements of the stand development

\subsubsection{Flagship station}

When we expand the advanced station measurements to cover the detailed structure and processes in the stand we obtain the flagship station which has the following measurements:

1. the measurements conducted at advanced forest stations

2. masses as well as protein, cellulose, lignin, starch and lipid concentrations in the components of ecosystem, i.e., trees and ground vegetation
3. protein, cellulose, lignin, starch and lipid concentrations in soil layers

4. isotopic composition (carbon, nitrogen, oxygen) of vegetation and soil layers

5. measurements of $\mathrm{CO}_{2}$ exchange, transpiration and VOC emissions at shoot level and from soil

6. water storage in soil, rainfall above and under the canopy, run off of water and concentrations of dissolved organic and inorganic carbon in runoff

7. inventories of animal (mammals, birds and insects) characteristics in the surrounding areas.

\subsection{Ocean and sea ice}

The oceans are a major reservoir of water and heat in the Earth system. Approximately $97 \%$ of water in the Earth is stored in oceans, and a water column of only $2.5 \mathrm{~m}$ thick has a heat capacity equal to a column throughout the atmosphere. The top layer of oceans, typically less than $200 \mathrm{~m}$ in depth, is usually well mixed due to wind-driven turbulence, but below it the water column is strongly stratified via vertical gradients in temperature and salinity. Exceptions to this pattern include ice-free oceans in high latitudes, where deep convection occurs in wintertime (Yashayaev and Loder, 2009). The atmospheric gases dissolve into the ocean water but their concentrations are rather low. The ion concentrations in the water, especially $\mathrm{Na}$ and $\mathrm{Cl}$, are high. Rich algae, microbe and animal fauna are living in the oceans.

The absorption of solar radiation warms the oceans, but the depth that solar radiation reaches is highly variable depending on the turbidity of the water. Evaporation and thermal radiation cool the top layer. Algae photosynthesis consumes, while respiration of living organism increases, $\mathrm{CO}_{2}$ concentration in the water, generating temporal $\mathrm{CO}_{2}$ concentration variations. Dimethyl sulphide (DMS) is produced in the oceans as a result of complicated set of processes involving photosynthetic carbon assimilation (e.g., Groene, 1995; Six et al., 2013; Park et al., 2014).

The oceans interact with the atmosphere via the exchange of momentum, heat, water vapor, trace gases and aerosols. The $\mathrm{CO}_{2}$ and DMS fluxes driven by photosynthesis are important for atmospheric carbon dioxide and DMS concentrations. About $7 \%$ of the ocean surface is covered by sea ice, and the recent rapid decline of sea ice in the Arctic is one of the most dramatic signals of the climate change (Meier et al., 2014). Oceans are essential for transportation of cargo and a major source of food for the mankind, which is reflected in the distribution of the global population: as much as $38 \%$ of people live within $50 \mathrm{~km}$ of the coastline (Kay and Alder, 2005).

The role of oceans in the climate system is related, among others, to (i) transport of heat from lower latitudes towards the poles, (ii) supply of water for evaporation and further to 
precipitation and, (iii) via the large heat capacity, dampening of diurnal, seasonal, and inter-annual variations in the air temperature. Compared with terrestrial regions, fewer climatological data are available from the oceans, sea ice, and the atmosphere above them. This example presents a conceptual plan for measurement stations in high-latitude oceans, where sea ice occurs for at least part of the year. While the standard and flux stations will yield essential information on the state and change of the marine climate system, Flagship stations are needed for better understanding and parameterization of small-scale physical processes in the system (Vihma et al., 2014).

\subsubsection{Standard station}

The standard stations provide measurements of properties that are essential for ocean-sea ice-atmosphere interaction. The stations are buoys deployed on ice floes or in the open ocean. Depending on the location and ice conditions, the buoys can be either drifting or moored ones. Due to buoy drift, the geographical grid does not keep constant, and a typical lifetime of a drifting station is of the order of a year. In coastal regions, moored stations have, however, much longer lifetimes. The measurements include atmospheric pressure and temperature profiles from the sea water through ice and snow to the air, with a $2 \mathrm{~cm}$ vertical resolution. The profile measurements also yield information on the temporal evolution of ice and snow thickness. In the case of drifting buoys, the GPS-based location data yield the ice drift or ocean current vector (a drogue is needed for the open ocean buoys). The data are transmitted via a satellite link.

\subsubsection{Flux station}

The flux station, either moored or drifting, is an advanced version of the standard station, where the capacity includes

1. the measurements made at the standard stations

2. temperature and wind profiles in the lowermost meters of the atmosphere

3. temperature, salinity and current profiles in the uppermost tens or hundreds of meters of sea water

4. surface sensible heat flux (the measurements of vertical gradients in 2-4 are essential in the case that the direct heat flux measurements will not be accurate enough due to various problems met at unmanned ocean stations, such as waves, spray droplets, and ice/snow accretion on the instruments)

5. upward and downward components of the solar shortwave and thermal long wave radiation (in most cases, good data will require sufficient electrical power for heating and ventilation of the sensor domes)
6. in case the climate at the station is not too harsh and necessary electrical power can be provided, also other measurements may be carried out, such as the water vapor and trace gas fluxes

7. $\mathrm{CO}_{2}$ and DMS concentrations in the water and air

\subsubsection{Flagship stations}

The Flagship stations provide the state-of-the art observations on the ocean and sea ice, as well as their interaction with the atmosphere. The stations are (a) either moored or drifting ice stations, capable in operating over a winter or even throughout the year, and (b) permanent coastal and/or archipelago stations. Accordingly, electrical power is provided, and the instruments and supporting structures are monitored and maintained. The measurements include

- all the measurements made at flux stations (including 5 and 6)

- snow and ice properties: including density, grain size and shape distributions, surface roughness, sastrugi, ice rafting and ridging, and portions of columnar and granular ice.

- $\mathrm{CO}_{2}, \mathrm{CH}_{4}$, VOC and DMS profiles in water and in the air

- temperature, light intensity and ion concentration profiles

- phytoplankton mass profiles

- fluxes of $\mathrm{CO}_{2}, \mathrm{CH}_{4}$, VOC and DMS

- profiles of key enzymes of photosynthesis

The continuous measurements at Flagship stations can be strongly supplemented by frequent missions by autonomous under-ice gliders, yielding data on, e.g., ocean temperature, salinity and dissolved gases. Also, within the limits of aviation regulations, Unmanned Aerial Systems can be operated from Flagship stations. These will yield data on the atmosphere as well as ocean and sea ice and ocean surface properties.

We stress that it will be challenging to establish Flagship stations in the open ocean, whereas the coastal ones will be easier. A year-round drifting station corresponding to our vision for a Flagship station is planned for the Arctic Ocean for 2019-2020 (see www.mosaicobservatory.org). For periods with no marine Flagship stations, we have to rely on data collected by standard and flux stations, as well as during research vessel cruises, which sometimes allow measurements comparable to those planned for the Flagship stations, but for a shorter duration. 


\section{Concluding remarks}

In order to understand global environmental changes, comprehensive and continuous observations are needed. Here we have presented a conceptual design of a global, hierarchical observation network that can provide tools and increased understanding to tackle the inter-connected environmental and societal challenges. The conceptual design relies on physical conservation laws of mass, energy and momentum, as well as on concentration gradients that act as driving forces for the atmosphere-biosphere exchange. The network is composed of standard, flux and/or advanced and flagship stations, each of which have specific and identified tasks. Each ecosystem type on the globe has its own characteristic features that need to be taken into consideration. The most comprehensive observations are envisioned to occur in flagship stations (see Hari et al., 2009), with which the process-level understanding can be expanded to continental and global scales together with advanced data analysis, earth system modelling and satellite remote sensing.

The successful operation of SMEAR (Station for Measuring Forest Ecosystem-Atmosphere Relations) stations and their scientific impact (e.g., Kulmala et al., 2014b) have shown that it is possible to utilize flagship stations in multiple ways. Particularly the progress in understanding feedback loops and biogenic secondary particle formation has been remarkable.

Globally, we will need about 50 flagship stations, 500 advanced and/or flux stations and 10000 standard stations. The estimated cost for those are about EUR 20 M, EUR $2 \mathrm{M}$ and EUR 10000 for each flagship, advanced and standard station, respectively. For marine stations, the costs might vary significantly. For example, a flagship station on the arctic sea ice could cost EUR $30 \mathrm{M}$. Although the total sum is around EUR $3000 \mathrm{M}$, it should not be too high when comparing this sum to the scale of the global change problem and some other existing infrastructures such as global observing systems made of satellites and large facilities making observations in the fields of elementary particle physics and astronomy. Since mankind is not able to solve grand challenges without hard data, i.e., data obtained using reliable, comprehensive and continuous observations, is essential to start construction of the necessary station network for archiving such data right now.

Acknowledgements. We are thankful to Pavel Kabat (IIASA) and Meinrat O. Andreae (the Max Planck Institute of Chemistry) for their support during the early stages of developing the SMEAR concept. Furthermore, we would like to thank the following persons: Congbin Fu and Aijun Ding (University of Nansing), Sergej Zilitinkevich (Finnish Meteorological Institute), Valery Bondur (AEROCOMOS), Nikolay Kasimov (Moscow State University) and Huadong Guo (RADI) supporting the distribution of the SMEAR concept to the global context. We acknowledge the support and funding from the following research infrastructure projects: ICOS
271878, ICOS-Finland No. 281255, ICOS-ERIC No. 281250, No. 259537, 218094, 255576, 286685, 280700, 259537 funded by Academy of Finland and EC-FP7 Aerosols, Clouds, and Trace gases Research InfraStructure Network (ACTRIS)-project. We also thank the Finnish Centre of Excellence in "Atmospheric Science - From Molecular and Biological processes to the Global Climate" (ATM) funded by Academy of Finland and the Nordic Centers of Excellence "Interactions between climate change and the cryosphere" (DEFROST) and "Cryosphere-atmosphere interactions in a changing Arctic climate" (CRAICC) (PEEX amendment to CRAICC-contact 26060) funded by Nordforsk.

Edited by: I. Salma

\section{References}

Arneth, A., Unger, N., Kulmala, M., and Andreae, M. O.: Clean the air, heat the planet, Science, 326, 672-673, 2009.

Arneth, A., Harrison, S. P., Zaehle, S., Tsigaridis, K., Menon, S., Bartlein, P. J., Feichter, J., Korhola, A., Kulmala, M., O’Donnell, D., Shurgers, G., Sorvari, S., and Vesala, T.: Terrestial biogeochemical feedbacks in the climate system, Nat. Geosci., 3, 525532, 2010.

Baldocchi, D.: "Breathing" of the terrestrial biosphere: lessons learned from a global netwrk of carbon dioxide flux measurement systems, Austr. J. Botany, 56, 1-26, 2008.

Bonan, G. B.: Forests and climate change: forcings, feedbacks, and the climate benefits of forests, Science, 320, 1444-1449, 2008.

Brasseur, G. P. and Roeckner, E.: Impact of improved air quality on the future evolution of climate, Geophys. Res. Lett., 32, L23704, doi:10.1029/2005GL023902, 2005.

Brasseur, G. P., Orlando, J. J., and Tyndall, G. S.: Atmospheric chemistry and global change, Oxford University Press, New York, 1999.

Carslaw, K. S., Boucher, O., Spracklen, D. V., Mann, G. W., Rae, J. G. L., Woodward, S., and Kulmala, M.: A review of natural aerosol interactions and feedbacks within the Earth system, Atmos. Chem. Phys., 10, 1701-1737, doi:10.5194/acp-10-17012010, 2010.

Challinor, A. J., Watson, J., Lobell, D. B., Howden, S. M., Smith, D. R., and Chhetri, N.: A meta-analysis of crop yields under climate change and adaptation, Nature Clim. Change, 4, 287-291, 2014.

Chin, M., Diehl, T., Tan, Q., Prospero, J. M., Kahn, R. A., Remer, L. A., Yu, H., Sayer, A. M., Bian, H., Geogdzhayev, I. V., Holben, B. N., Howell, S. G., Huebert, B. J., Hsu, N. C., Kim, D., Kucsera, T. L., Levy, R. C., Mishchenko, M. I., Pan, X., Quinn, P. K., Schuster, G. L., Streets, D. G., Strode, S. A., Torres, O., and Zhao, X.-P.: Multi-decadal aerosol variations from 1980 to 2009: a perspective from observations and a global model, Atmos. Chem. Phys., 14, 3657-3690, doi:10.5194/acp-14-3657-2014, 2014.

Ding, A. J., Fu, C. B., Yang, X. Q., Sun, J. N., Petäjä, T., Kerminen, V.-M., Wang, T., Xie, Y., Herrmann, E., Zheng, L. F., Nie, W., Liu, Q., Wei, X. L., and Kulmala, M.: Intense atmospheric pollution modifies weather: a case of mixed biomass burning with fossil fuel combustion pollution in eastern China, Atmos. Chem. Phys., 13, 10545-10554, doi:10.5194/acp-13-10545-2013, 2013.

Elmendorf S. C., Henry, G. H. R., Hollister, R. D., Björk, R. G., Boulanger-Lapointe, N., Cooper, E. J., Cornelissen, J. H. C., Day, 
T. A., Dorrepaal, E., Elumeeva, T. G., Gill, M., Gould, W. A., Harte, J., Hik, D. S., Hofgaard, A., Johnson, D. R., Johnstone, J. F., Jónsdóttir, I. S., Jorgenson, J. C., Klanderud, K., Klein, J. A., Koh, S., Kudo, G., Lara, M., Lévesque, E., Magnússon, B., May, J. L., Mercado-Diaz, J. A., Michelsen, A., Molau, U., MyersSmith, I. H.,. Oberbauer,S. F., Onipchenko, V. G., Rixen, C., Martin Schmidt, N., Shaver, G. R., Spasojevic, M. J., Pórhallsdóttir, P., E., Tolvanen, A., Troxler, T., Tweedie, C. E., Villareal, S., Wahren, C.-H., Walker, X., Webber, P. J., Welker, J. M., and Wipf, A.: Plot-scale evidence of tundra vegetation change and links to recent summer warming, Nature Clim. Change, 2, 453457, 2012.

Estrada, F., Perron, P., and Martinez-Lopez, B.: Statistically derived contributions of diverse human influences to twentieth-century temperature changes, Nat. Geosci., 6, 1050-1055, 2013.

Fiore, A. M., Naik, V., Spracklen, D. V., Steiner, A., Unger, N., Prather, M., Bergmann, D., Cameron-Smith, P. J., Cionni, I., Collins, W. J., Dalsøren, S., Eyring, V., Folberth, G. A., Ginoux, P., Horowitz, L. W., Josse, B., Lamarque, J.-F., MacKenzie, I. A., Nagashima, T., O’Connor, F., M., Righi, M., Rumbold, S. T., Shindell, D. T., Skeie, R. B., Sudo, K., Szopa, S., Takemura T., and Zeng, G.: Global air quality and climate: critical review, Chem. Soc. Rev, 41, 6663-6683, 2012.

Granier, C., Bessagnet, B., Bond, T., D’Angiola, A., van der Gon, H. D., Frost, G. J., Heil, A., Kaiser, H. J., Kinne S., Klimont, Z., Kloster, S., Lamarque, J.-F., Liousse, C., Masui, T., Meleux, F., Mieville, A., Ohara, T., Raut, J.-C., Riahi, K., Schultz, M. G., Smith, S. J., Thompson, A., van Aardenne, J., van der Werf, G. R., and van Vuuren, D. P.: Evolution of anthropogenic and biomass burning emissions of air pollutants at global and regional scales during the 1980-2010 period, Climatic Change, 109, 163-190, 2011.

Groene, T.: Biogenic production and consumption of dimethylsulfide (DMS) and dimethylsulfoniopropionate (DMSP) in the marine epipelagic zone: a review, J. Mar. Syst. 6, 191-209, 1995.

Hari, P., Andreae, M. O., Kabat, P., and Kulmala, M.: A comprehensive network of measuring stations to monitor climate change, Boreal Environ. Res., 14, 442-446, 2009.

Haywood, J. M., Bellouin, N., Jones, A., Boucher, O., Wild, M., and Shine, K. P.: The roles of aerosol, water vapor and cloud in future global dimming/brightening, J. Geophys. Res., 116, D20203, doi:10.1029/2011JD016000, 2011.

Horton, D. E., Skinner, C. B., Singh, D., and Diffenbaugh, N. S.: Occurrence and persistence of future atmospheric stagnation events, Nature Clim. Change, 4, 698-703, 2014.

Ilvesniemi, H. and Liu, C.: Biomass distribution in a young Scots pine stand, Boreal Environ. Res., 6, 3-8, 2001.

Ilvesniemi, H., Levula, J., Ojansuu, R., Kolari, P., Kulmala, L., Pumpanen, J., Launiainen, S., Vesala, T., and Nikinmaa, E.: Long-term measurements of the carbon balance of a boreal Scots pine dominated forest ecosystem, Boreal Environ. Res., 14, 731753, 2009.

Inness, A., Baier, F., Benedetti, A., Bouarar, I., Chabrillat, S., Clark, H., Clerbaux, C., Coheur, P., Engelen, R. J., Errera, Q., Flemming, J., George, M., Granier, C., Hadji-Lazaro, J., Huijnen, V., Hurtmans, D., Jones, L., Kaiser, J. W., Kapsomenakis, J., Lefever, K., Leitão, J., Razinger, M., Richter, A., Schultz, M. G., Simmons, A. J., Suttie, M., Stein, O., Thépaut, J.-N., Thouret, V., Vrekoussis, M., Zerefos, C., and the MACC team: The MACC reanalysis: an 8 yr data set of atmospheric composition, Atmos. Chem. Phys., 13, 4073-4109, doi:10.5194/acp-13-4073-2013, 2013.

IPCC: Climate Change 2013: The Physical Science Basis. Working Group I Contribution to the Fifth Assessment Report of the Intergovernmental Panel on Climate Change, edited by: Stocker, T. F., Qin, D., Plattner, G.-K., Tignor, M., Allen, S. K., Boschung, J., Nauels, A., Xia, Y., Bex, V., and Midgley, P. M.: Cambridge University Press, Cambridge, United Kingdom and New York, NY, USA, 2013.

Jones, G. S., Stott, P. A., and Christidis, N.: Attribution of observed historical near-surface temperature variations to anthropogenic and natural causes using CMIP5 simulations, J. Geophys. Res., 118, 4001-4024, 2013.

Kay, R. and Alder, J.: Coastal Planning and Management, 2nd Edn., Taylor and Francis, 400 pp., 2005.

Kulmala, M., Suni, T., Lehtinen, K. E. J., Dal Maso, M., Boy, M., Reissell, A., Rannik, Ü., Aalto, P., Keronen, P., Hakola, H., Bäck, J., Hoffmann, T., Vesala, T., and Hari, P.: A new feedback mechanism linking forests, aerosols, and climate, Atmos. Chem. Phys., 4, 557-562, doi:10.5194/acp-4-557-2004, 2004.

Kulmala, M., Asmi, A., Lappalainen, H. K., Baltensperger, U., Brenguier, J.-L., Facchini, M. C., Hansson, H.-C., Hov, Ø., O'Dowd, C. D., Pöschl, U., Wiedensohler, A., Boers, R., Boucher, O., de Leeuw, G., Denier van der Gon, H. A. C., Feichter, J., Krejci, R., Laj, P., Lihavainen, H., Lohmann, U., McFiggans, G., Mentel, T., Pilinis, C., Riipinen, I., Schulz, M., Stohl, A., Swietlicki, E., Vignati, E., Alves, C., Amann, M., Ammann, M., Arabas, S., Artaxo, P., Baars, H., Beddows, D. C. S., Bergström, R., Beukes, J. P., Bilde, M., Burkhart, J. F., Canonaco, F., Clegg, S. L., Coe, H., Crumeyrolle, S., D’Anna, B., Decesari, S., Gilardoni, S., Fischer, M., Fjaeraa, A. M., Fountoukis, C., George, C., Gomes, L., Halloran, P., Hamburger, T., Harrison, R. M., Herrmann, H., Hoffmann, T., Hoose, C., Hu, M., Hyvärinen, A., Hõrrak, U., Iinuma, Y., Iversen, T., Josipovic, M., Kanakidou, M., Kiendler-Scharr, A., Kirkevåg, A., Kiss, G., Klimont, Z., Kolmonen, P., Komppula, M., Kristjánsson, J.-E., Laakso, L., Laaksonen, A., Labonnote, L., Lanz, V. A., Lehtinen, K. E. J., Rizzo, L. V., Makkonen, R., Manninen, H. E., McMeeking, G., Merikanto, J., Minikin, A., Mirme, S., Morgan, W. T., Nemitz, E., O’Donnell, D., Panwar, T. S., Pawlowska, H., Petzold, A., Pienaar, J. J., Pio, C., Plass-Duelmer, C., Prévôt, A. S. H., Pryor, S., Reddington, C. L., Roberts, G., Rosenfeld, D., Schwarz, J., Seland, Ø., Sellegri, K., Shen, X. J., Shiraiwa, M., Siebert, H., Sierau, B., Simpson, D., Sun, J. Y., Topping, D., Tunved, P., Vaattovaara, P., Vakkari, V., Veefkind, J. P., Visschedijk, A., Vuollekoski, H., Vuolo, R., Wehner, B., Wildt, J., Woodward, S., Worsnop, D. R., van Zadelhoff, G.-J., Zardini, A. A., Zhang, K., van Zyl, P. G., Kerminen, V.-M., S Carslaw, K., and Pandis, S. N.: General overview: European Integrated project on Aerosol Cloud Climate and Air Quality interactions (EUCAARI) - integrating aerosol research from nano to global scales, Atmos. Chem. Phys., 11, 13061-13143, doi:10.5194/acp11-13061-2011, 2011.

Kulmala, M., Nieminen, T., Nikandrova, A., Lehtipalo, K., Manninen, H. E., Kajos, M. K., Kolari, P., Lauri, A., Petäjä, T., Krejci, R., Hansson, H.-C., Swietlicki, E., Lindroth, A., Christensen, T. R., Arneth, A., Hari, P., Bäck, J., Vesala, T., and Kerminen, V.$\mathrm{M}$.: $\mathrm{CO}_{2}$-induced terrestrial feedback mechanism: From carbon 
sink to aerosol source and back, Boreal Environ. Res., 19, suppl. B, 122-131, 2014a.

Kulmala, M., Lappalainen, H. K., Bäck, J., Laaksonen, A., Nikinmaa, E., Riekkola, M.-L., Vesala, T., Viisanen, Y., Aalto, T., Boy, M., Dal Maso, M., Ehn, M., Hakola, H., Hari, P., Hartonen, K., Hämeri, K., Hölttä, T., Junninen, H., Järvi, L., Kurten, T., Lauri, A., Laurila, T., Lehtipalo, K., Lihavainen, H., Lintunen, A., Mammarella, I., Manninen, H. E., Petäjä, T., Pihlatie, M., Pumpanen, J., Rinne, J., Romakkaniemi, S., Ruuskanen, T., Sipilä, M., Sorvari, S., Vehkamäki, H., Virtanen, A., Worsnop, D. R., and Kerminen, V.-M.: Finnish Centre of Excellence in Physics, Chemistry, Biology and Meteorology of Atmospheric Composition and Climate Change: summary and outlook, Boreal Environ. Res., 19, suppl. B, 2-19, 2014b.

Kulmala, M., Lappalainen, H. K., Petäjä, T., Kurten, T., Kerminen, V.-M., Viisanen, Y., Hari, P., Sorvari, S., Bäck, J., Bondur, V., Kasimov, N., Kotlyakov, V., Matvienko, G., Baklanov, A., Guo, H. D., Ding, A., Hansson, H.-C., and Zilitinkevich, S.: Introduction: The Pan-Eurasian Experiment (PEEX) multidisciplinary, multiscale and multicomponent research and capacity-building initiative, Atmos. Chem. Phys., 15, 1308513096, doi:10.5194/acp-15-13085-2015, 2015.

Laothawornkitkul, J., Taylor, J. E., Paul, N. D., and Hewitt, C. N.: Biogenic volatile organic compounds in the Earth System, New Phytologist, 183, 27-51, 2009.

Lamarque, J.-F., Bond, T. C., Eyring, V., Granier, C., Heil, A., Klimont, Z., Lee, D., Liousse, C., Mieville, A., Owen, B., Schultz, M. G., Shindell, D., Smith, S. J., Stehfest, E., Van Aardenne, J., Cooper, O. R., Kainuma, M., Mahowald, N., McConnell, J. R., Naik, V., Riahi, K., and van Vuuren, D. P.: Historical (1850-2000) gridded anthropogenic and biomass burning emissions of reactive gases and aerosols: methodology and application, Atmos. Chem. Phys., 10, 7017-7039, doi:10.5194/acp10-7017-2010, 2010.

Lappalainen, H. K., Petäjä, T., Kujansuu, J., Kerminen, V-M., Shvidenko, A., Bäck, J., Vesala, T., Vihma, T., de Leeuw, G., Lauri, A., Ruuskanen, T., Flint, M., Zaitseva, N., Arshinov, M., Spracklen, D., Arnold, S., Juhola, S., Lihavainen, H., Viisanen, Y., Chubarova, N., Filatov, N., Skorokhod, A., Elansky, N., Dyukarev, E., Hari, P., Kotlyakov, V., Kasimov, N., Bondur, V., Matvienko, G., Baklanov, A., Guo H., Zilitinkevich, S., and Kulmala, M.: Pan-Eurasian Experiment (PEEX) - a research initiative meeting the grand challenges of the changing environment of the northern Pan-Eurasian arctic-boreal areas, J. Geogr. Environ. Sustain., 2, 13-48, 2014.

Lim, S. S., Vos, T., Flaxman, A. D., Danaei, G., Shibuya, K., AdairRohani, H., Al Mazroa, M. A., Amann, M., Anderson, H. R., Andrews, K. G., Aryee, M., Atkinson, C., Bacchus, L. J., Bahalim, A. N., Balakrishnan, K., Balmes, J., Barker-Collo, S., Baxter, A., Bell, M. L., Blore, J. D., Blyth, F., Bonner, C., Borges, G., Bourne, R., Boussinesq, M., Brauer, M., Brooks, P., Bruce, N. G., Brunekreef, B., Bryan-Hancock, C., Bucello, C., Buchbinder, R., Bull, F., Burnett, R. T., Byers, T. E., Calabria, B., Carapetis, J., Carnahan, E., Chafe, Z., Charlson, F., Chen, H., Chen, J. C., Cheng, A. T.-A., Child, J.-C., Cohen, A., Colson, K. E., Cowie, B. C., Darby, S., Darling, S., Davis, A., Degenhardt, L., Dentener, F., Jarlais, D. C. D., Devries, K., Dherani, M., Ding, E. L., Dorsey, E. R., Driscoll, T., Edmond, K., Ali, S. E., Engell, R. E., Erwin, P. J., Fahimi, S., Falder, G., Farzadfar, F., Ferrari, A.,
Finucane, M. M., Flaxman, S., Fowkes, F. G. R., Freedman, G., Freeman, M. K., Gakidou, E., Ghosh, S., Giovannucci, E., Gmel, G., Graham, K., Grainger, R., Grant, B.., Gunnell, D., Gutierrez, H. R., Hall, W., Hoek, H. W., Hogan, A., Hosgood, H. D., Hoy, D., Hu, H., Hubbell, B. J., Hutchings, S. J., Ibeanusi, S. E., Jacklyn, G. L., Jasrasaria, R., Jonas, J. B., Kan, H., Kanis, J. A., Kassebaum, N., Kawakami, N., Khang, Y.-H., Khatibzadeh, K., Khoo, J.-P., Kok, C., Laden, F., Lalloo, R., Lan, Q., Lathlean, T., Leasher, J. L., Leigh, J. Li, Y., Lin, J. K., Lipshultz, S. E., London, S., Lozano, R., Lu, Y., Mak, J., Malekzadeh, R., Mallinger, L., Marcenes, W., March, L., Marks, R., Martin, R., McGale, P., McGrath, J. Mehta, S., Memish, Z. A., Mensah, G. A., Merriman, T. R., Micha, R., Michaud, C., Mishra, V., Hanafiah, K. M., Mokdad, A. A. Morawska, L., Mozaffarian, D., Murphy, T., Naghavi, M., Neal, B., Nelson, P. K., Nolla, J. M., Norman, R., Olives, C., Omer, S. B., Orchard, J. Osborne, R., Ostro, B., Page, A., Pandey, K. D., Parry, C. D. H., Passmore, E., Patra, J., Pearce, N., Pelizzari, P. M., Petzold, M., Phillips, M. R., Pope, D., Pope, C. D., Powles, J., Rao, M., Razavi, H., Rehfuess, E. A., Rehm, J. T., Ritz, B., Rivara, F. B., Roberts, T., Robinson, C., RodriguezPortales, J. A., Romieu, I., Room, R., Rosenfeld, L. C., Roy, A., Rushton, L., Salomon, J. A., Sampson, U., Sanchez-Riera, L., Sanman, E., Sapkota, A., Seedat, S., Shi, P., Shield, K., Shivakoti, R., Singh, G. M., Sleet, D. A., Smith, E., Smith, K. R., Stapelberg, N. J. C., Steenland, K., Stöckl, H., Stovner, L. J., Straif, K., Straney, L., Thurston, G. D., Tran, J. H., Van Dingenen, R., van Donkelaar, A., Veerman, J. L., Vijayakumar, L., Weintraub, R., Weissman, M. M., White, R. A., Whiteford, H., Wiersma, S. T., Wilkinson, J. D., Williams, H. C., Williams, W., Wilson, N., Woolf, A. D., Yip, P., Zielinski, J. M., Lopez, A. D., Murray, C. J. L., and Ezzati, M.: A comparative risk assessment of burden of disease and injury attributable to 67 risk factors and risk factor clusters in 21 regions, 1990-2010: a systematic analysis for the Global Burden of Disease Study 2010, Lancet, 380, 2224-2260, 2012.

Mahowald, N.: Aerosol indirect effects on biogeochemical cycles and climate, Science, 334, 794-796, 2011.

Meier, W. N., Hovelsrud, G. K., van Oort, B. E. H., Key, J. R., Kovacs, K. M., Michel, C., Haas, C., Granskog, M. A., Gerland, S., Perovich, D. K., Makshtas, A., and Reist, J. D.: Arctic sea ice in transformation: A review of recent observed changes and impacts on biology and human activity, Rev. Geophys., 52, 185217, doi:10.1002/2013RG000431, 2014.

Müller, C., Eickhout, B., Zaehle, S., Bondeau, A., Cramer, W., and Lucht, W.: Effects of changes in $\mathrm{CO}_{2}$, climate, and land use on the carbon balance of the land biosphere during the 21st century, J. Geophys. Res., 112, G02032, doi:10.1029/2006JG000388, 2007.

Naik, V., Horowitz, L. W., Fiore, A. M., Ginoux, P., Mao, J., Aghedo, A. M., and Levy II, H.: Impact of preindustrial to present-day changes in short-lived pollutant emissions on atmospheric composition and climate change, J. Geophys. Res., 118, 8086-8110, 2013.

Nobre, C. Brasseur, G. P., Shapiro, M. A., Lahsen, M., Brunet, G., Busalacchi, A. J., Hibbard, K., Seitzinger, S., Noone, K., and Ometto J. P.: Addressing the complexity of the Earth system, B. Am. Meteorol. Soc., 91, 1389-1396, 2010. 
Overland, J. E., Wang, M., Walsh, J. E. and Stroeve, J. C.: Future Arctic climate changes: Adaptation and mitigation time scales, Earth's Future, 2, 68-74, 2013.

Paasonen, P., Asmi, A., Petäjä, T., Kajos, M. K., Äijälä, M, Junninen, H., Holst, T., Abbatt, J. P. D., Arneth, A., Birmili, W., Denier van der Gon, H., Hamed, A., Hoffer, A., Laakso, L., Laaksonen, A., Leaitch, W. R., Plass-Dulmer, C., Pryor, S. C., Räisänen, P., Swietlicki, E., Wiedensohler, A., Worsnop, D. R., Kerminen, V.-M., and Kulmala, M.: Warming-induced increase in aerosol number concentration likely to moderate climate change, Nat. Geosci., 6, 438-442, 2013.

Park, K.-T., Lee, K., Shin, K., Yang, E. J., Hyun, B., Kim. J.-M., Joh, J. H., Kim, M., Kong, B., Choi, D. H., Choi, S.-J., Jang, P.-G., and Jeong, H. J.: Direct linkage between dimethyl sulfide production and microzooplankton grazing, resulting from prey composition change under high partial pressure of carbon dioxide conditions, Environ. Sci. Technol., 48, 4750-4756, 2014.

Petäjä, T., Järvi, L., Kerminen, V.-M., Ding, A., Sun, J., Nie, W., Kujansuu, J., Virkkula, A., Yang, X., Fu, C., Zilitinkevich, S., and Kulmala, M.: Enhanced air pollution via aerosol-boundary layer feedback in China, Scientific Reports, Scientific Reports, 6, 18998, doi:10.1038/srep18998, 2016.

Raes, F., Liao, H., Chen, T.-W., and Seinfeld, J. H.: Atmospheric chemistry-climate feedbacks, J. Geophys. Res., 115, D12121, doi:10.1029/2009JD013300, 2010.

Raupach, M. R. and Ganadell, J. G.: Carbon and the Anthropocene, Curr. Opin. Environ. Sustain., 2, 210-218, 2010.

Ren, L., Arkin, P., Smith, T. M., and Shen, S. S. P.: Global precipitation trends in 1900-2005 from a reconstruction and coupled model simulations, J. Geophys. Res., 118, 1679-1589, 2013.

Rockström, J., Steffen, W., Noone, K. Persson, Å., Chapin, III, F. S., Lambin, E. F., Lenton T. M., Scheffer, M., Folke, C., Schellnhuber, H. J., Nykvist, B., de Wit, C. A., Hughes, T., van der Leeuw, S., Rodhe, H., Sörlin, S., Snyder, P. K., Costanza, R., Svedin, U., Falkenmark, M., Karlberg, L., Corell, R. W., Fabry, V. J., Hansen, J., Walker, B., Liverman, D., Richardson, K., Crutzen, P., and Foley, J. A.: A safe operating space for humanity, Nature, 461, 472-475, 2009.

Rosenfeld, D., Sherwood, S., Wood, R., and Donner, L.: Climate effects of aerosol-cloud interactions, Science, 343, 379-380, 2014.

Santer, B. J., Painter, J. F., Bonfils, C., Mears, C. A., Solomon, S., Wigley, T. M. L., Gleckler, P. J., Schmidt, G. A., Doutriaux, C., Gillett, N. P., Taylor, K. E., Thorne, P. W., and Wentz, F. J.: Human and natural influences on the changing thermal structure of the atmosphere, P. Natl. Acad. Sci. USA, 110, 17235-17240, 2013.

Savva, Y. and Berninger, F.: Sulphur deposition causes a large-scale growth decline in boreal forests in Eurasia, Global Biogeochem. Cy., 24, GB3002, doi:10.1029/2009GB003749, 2010.

Schwartz, S. E.: Feedback and sensitivity in an electrical circuit: an analog for climate models, Climatic Change, 106, 315-326, 2011.
Seinfeld, J. H. and Pandis, S. N.: Atmospheric Chemistry and Physics: From Air Pollution to Climate Change, John Wiley, New York, 2006.

Shindell, D., Kuylenstierna, J. C. I., Vignati, E., van Dingenen, R., Amann, M., Klimont, Z., Anenberg, S. C., Muller, N., JanssensMaenhout, G, Raes, F., Schwartz, J., Faluvegi, G., Pozzoli, L., Kupiainen, K., Höglund-Isakson, L., Emberson, L., Streets, D., Ramanathan, V., Hicks, K., Oanh, N. T. K., Milly G., Williams, M., Demkine, V., and Fowler, D.: Simultaneously mitigating near-term climate change and improving human health and good security, Science, 335, 183-189, 2012.

Silva, R. A., West, J. J., Zhang, Y., Anenberg, S. C., Lamarque, J.-F., Shindell, D. T., Collins, W. J., Dalsoren, S., Faluvegi, G., and Folberth, G.: Global premature mortality due to anthropogenic outdoor air pollution and the contribution of past climate change, Environ. Res. Lett., 8, 034005, doi:10.1088/17489326/8/3/034005, 2013.

Six, K. D., Kloster, S., Ilyina, T., Archer, S. D., Zhang, K., and Maier-Reimer, E.: Global warming amplified by reduced sulphur fluxes as a result of ocean acidification, Nature Clim. Change, 3, 975-978, doi:10.1038/nclimate1981, 2013.

Stephens, G. L., Li, J., Wild, M., Clayson, C. A., Loeb, N., Kato, S., L'Ecuyer, T., Stackhouse Jr., P. W., Lebsock, M., and Andrews, T.: An update on Earth's energy balance in light of the latest global observations, Nat. Geosci., 5, 691-696, 2012.

Tai, A. P. K., Val Martin, M., and Heald, C. L.: Threat to future global food security from climate change and ozone air pollution, Nature Clim. Change, 4, 817-821, 2014.

Urbanski, S., Barford, C., Wofsy S., Kucharik, C., Pyle, E., Budney, J., McKain, K., Fitzjarrald, D., Czikowsky, M., and Munger, J. W.: Factors controlling $\mathrm{CO}_{2}$ exchange on timescales from hourly to decadal at Harvard forest, J. Geophys. Res., 112, G02020, doi:10.1029/2006JG000293, 2007.

Vihma, T., Pirazzini, R., Fer, I., Renfrew, I. A., Sedlar, J., Tjernström, M., Lüpkes, C., Nygård, T., Notz, D., Weiss, J., Marsan, D., Cheng, B., Birnbaum, G., Gerland, S., Chechin, D., and Gascard, J. C.: Advances in understanding and parameterization of small-scale physical processes in the marine Arctic climate system: a review, Atmos. Chem. Phys., 14, 9403-9450, doi:10.5194/acp-14-9403-2014, 2014.

Wanner, H., Beer, J., Bütikofer, J., Crowley, T. J., Cubasch, U., Flückiger, J., Goosse, H., Grosjean, M., Joos, F., Kaplan, J. O., Küttel, M., Müller, S. A., Prentice, I. C., Solomina, O., Stocker, T. F., Tarasov, P., Wagner, M., and Widmann, M.: Mid- to Late Holocene climate change: an overview, Quaternary Sci. Rev., 27, 1791-1828, 2008.

Wheeler, T. and von Braun, J.: Climate change impacts on global food security Science, 341, 508-513, 2013.

Yashayaev, I. and Loder, J. W.: Enhanced production of Labrador Sea Water in 2008, Geophys. Res. Lett., 36, L01606, doi:10.1029/2008GL036162, 2009. 